症例

食道裂孔ヘルニアを合併した Morgagni 孔ヘルニアの 1 例

熊本大学第 1 外科 (主任：北村信夫教授), 山鹿市立病院外科*

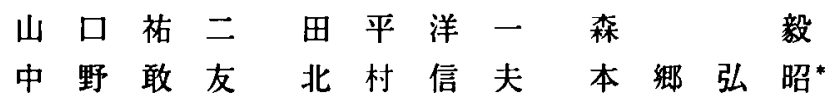

大網をヘルニア内容とする Morgagni 孔ヘルニアで，食道裂孔ヘルニアを合併した症 例を経験した．症例は 80 歳女性で胸写にて右下肺野に突出する境界明瞭な腫痹を認め, CT で脂肪成分が疑われ, MRI では腹腔との連続が疑われた. 手術は胸骨糍切開アプロー チで行いマーレックスメッシュによりヘルニア孔を閉鎖した. Morgagni 孔へルニアの 診断にCT.MRI は重要であり,胸骨縦切開アプローチによる手術は有用な治療法と考え られた.

索引用語：Morgagni 孔ヘルニア, 食道裂孔ヘルニア, 胸骨綎切開

\section{はじめに}

Morgagni 孔ヘルニアは横隔膜ヘルニアの中で最も 頻度の少ない，稀な疾患である．今回，われわれは滑 脱型食道裂孔へルニアを合併した，大網のみを内容と する Morgagni 孔ヘルニア症例を経験したので，若干 の文献的考察を加え報告する.

$$
\text { 症例 }
$$

患者： 80 歳，女性.

主訴：胸痛.

家族歴：特記すべきことなし．

既往歴: 20 年前, 心筋梗塞.

現病歴：平成 8 年 4 月胸部 X線にて, 右前絴隔に異 常陰影を指摘されたが，無症状のため放置していた。 9 月に胸痛にて近医を受診し，上部消化管内視鏡検査 にて食道裂孔へルニアを指摘され，手術目的にて当科 入院となった.

入院時現症：身長 $142 \mathrm{~cm}$, 体重 $57 \mathrm{~kg}$, 軽度肥满. 負 血, 黄疸無く, 呼吸音も正常であった. 腹部にも異常 所見を諗めなかった。

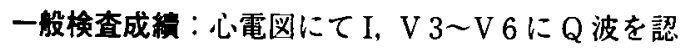
めたが，心葴超音波検査では心室壁の動きは良好に保 たれていた. 他に異常所見は認めなかった。

胸部 X 線所見（图 1)：右下肺野に横隔膜より立ち 上がり急俊, 辺粶整, 境界明瞭な腫瘤影を認めた。 心 陰影との silette sign および extrapleural signは陰性

1998 年 5 月 18 日受付 1999 年 1 月 14 日採用
であった。

胸部 CT 所見 (图 2)：縦隔より右前下肺野に突出す る大きさ $18 \times 8.5 \mathrm{~cm}$ の腫㿔影を認めた。腫瘦は脂肪と ほほ同レベルの均一な densityで, 境界明瞭, 辺緑整 で，内部にやや high density な索状の血管を疑わせる 陰影を認めた。

胸部 MRI 所見（図3）：T 1 強調矢状断にて維隔よ り，下葉を圧排するように胸腔内に突出する，脂肪と 同様な intensityをもつ境界明瞭, 辺縁整, 内部信号均 一な腫瘤を認めた。その腫㿎影は同じ intensityのまま 腹腔内人と続いており，腹腔内との連続性が疑われた。

上部消化管透視検查（図4）：胃は $3 \mathrm{~cm}$ ほどの滑脱 型食道裂孔へルニアを認めたが，立位充盈像にて胃の 偏位等の異常は認めなかった，頭低位としても食道へ の逆流は認めなかった。

以上より, Morgagni 孔ヘルニアと診断したが, 胸腺 脂肪腫も否定できず，1997年 1 月 11 日手術を行った。

手術所見（図 5)：胸骨縦切開にて前維隔に達した。 維隔内を検すると，心爱に接した，正中やや右側の胸 骨裏面に縦隔より胸腔内に突出する大きさ $10 \mathrm{~cm}$ 大 の表面平滑ほほ球形の腫瘤を認めた。腫瘤は用手圧迫 により容易に縮小した，腫瘤を切開すると内容は大網 であった．以上より，大網をへルニア内容とする Morgagni 孔ヘルニアと診断した. 大網を烡より鋭的鈍的 に剥離し腹腔内へ還納した。へルニア門は 4 横指大で あった. ヘルニア䍻を切除した後, ヘルニア門を閉鎖 した.この際, 横隔膜は稀薄, 脆弱であったため, 直 


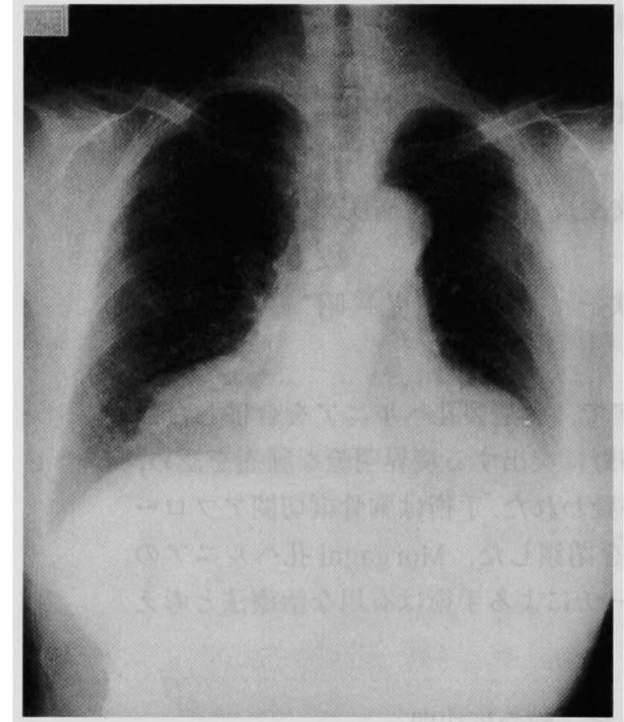

图 1 胸部 X 線写真（正面立位）：右心横䏂膜角に突 出する腫瘤影がみられる。

接䋖合では横隔膜へ緊張がかかり過ぎると考え，ソフ トマーレックスメッシュを用いて，ヘルニア門を閉鎖 した，食道裂孔へルニアは，現在無症状であり，逆流 の所見も認めないことより，経過観察することとした。

術後経過：順調に経過し，2 週間で退院した. 術後 6 力月の現在, 逆流性食道炎も含めて, 胸部・腹部症状 を認めない.

\section{考察}

Morgagni 孔ヘルニアは横隔膜ヘルニアのうち $3 \%$ と最も少なく，横隔膜の胸肋三角の裂孔をへルニア門 として発生する. 発症年齢は，小児および50 歳以上の 高年龄層に多い．高齡者では女性に多く，肥満，出産， 加齢による腹壁，横隔膜の脆弱化などの関与が考えら れている゙。本症の食道裂孔へルニア合併例の報告は 少なく著者の調べ得た限りではこれまでに 11 例の報 告がある. そのうち 10 例までが高齢の女性である. 本 例も 80 歳女性に生じたもので, 横隔膜が稀薄で, 食道 裂孔ヘルニアを合併していた。

また，術前診断に関しては，土肥ら ${ }^{2}$ は，Morgagni 孔へルニアのうち，大網のみを内容物とした例は 25 \%で，そのうち術前に確定診断がついたものは $22 \%$, 維隔腫瘍を否定できなかったものは $53 \%$ であったと 報告している．本症例でも内容が大網のみであり，胸 腺脂肪腫を完全に否定できなかった．鑑別診断の手段 としては人工気腹撮影浮，選択的腹腔動脈造影検

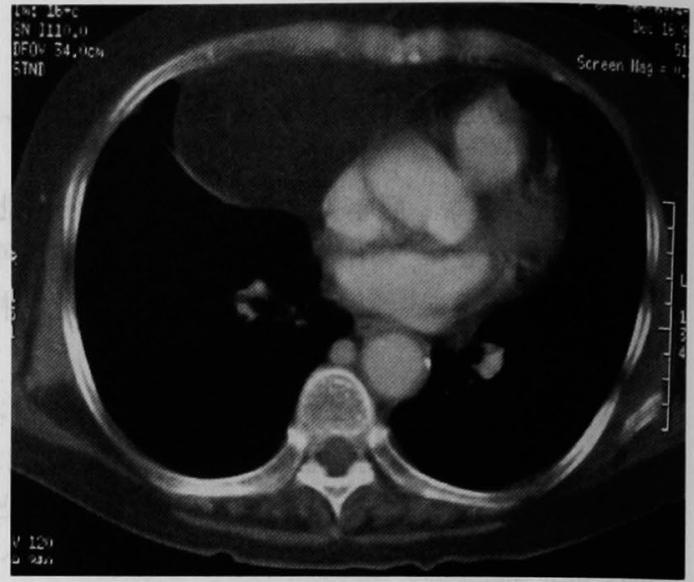

图 2 胸部 CT：肝腹側に，脂肪と同様の density 持った腫瘤影が認められる。

查 ${ }^{56)}$ ，注腸造影検查 ${ }^{15577}$ が報告されており，注腸造影 検查では大網の毫引による横行結腸の逆U字型偏位 が診断に有用であったとする文献も見受けられる゙。 本例では食道裂孔ヘルニアに対し，上部消化管透視を 術前に行ったが，胃の偏位等はみられなかった。なお， 血管造影, 注腸透視は施行しなかった。

近年, Morgagni ヘルニアの診断に MRI が有効とす る報告が散見される 腔内との連続性が示唆され，またCT で肝左葉の前面 に胸腔から連続する脂肪組織を認め，最近の高解像度 のCT，MRI を用いれば確実な診断が可能であると考 えられた。

次に, 手術経路であるが, Morgagni ヘルニアに对し ては主に，経胸的および経腹的アプローチがあり，と ちらを選ぶかは症例ごとに十分検討する必要がある. 今回，われわれは胸骨縦切開によるアプローチを行っ たが，その一番の理由としては，肺紸隔疾患の可能性 を考虑したためであった．また本例では，食道裂孔へ ルニアも合併していたが，治療を要しない無症候性の ヘルニアであった，そのため，食道裂孔ヘルニアの悪 化を回避するために、メッシュを用いて横隔膜に強い 緊張をかけずに補強を行った，胸骨縦切開アプローチ は，肥満の有無に関わらず直視下にヘルニア門を見る ことができ，操作が容易で，また胸腔内の瘾着剥離も 容易に行えるという利点があった。このように, 肥蔳, 横隔膜の脆弱化というこの疾患の特徴を考えた場合， 胸骨縦切開によるアプローチは Morgagni 孔ヘルニア に対して有用な経路の一つと考えられた。 


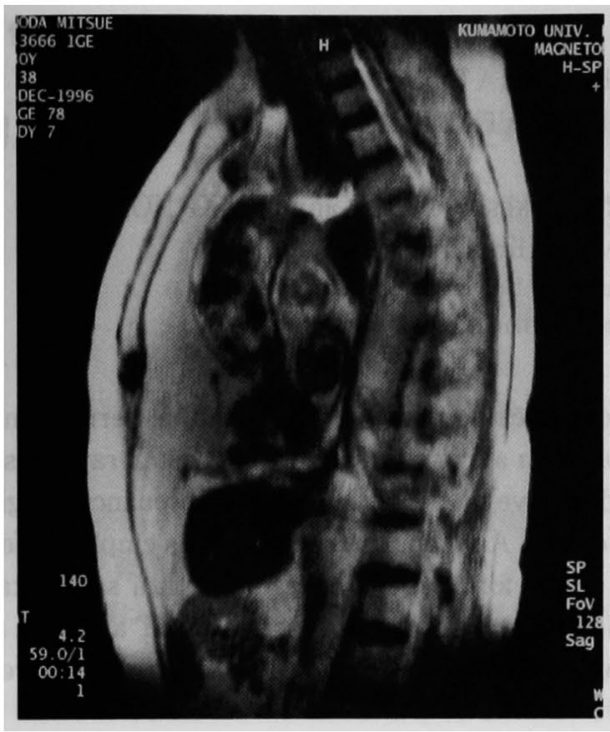

图 3 胸部 MRI (T 1 強調画像)：腹腔から右前綎隔へ 連秸する，均一な intensity の畽痹影が認められる。

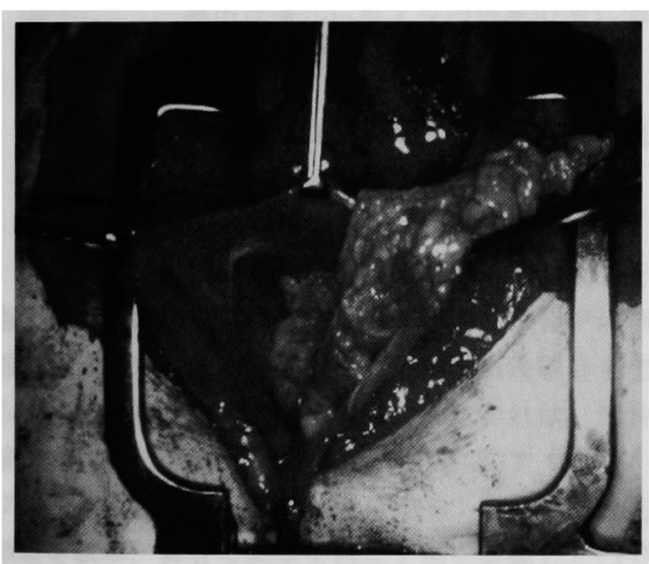

图 5 術中写真：ヘルニア童を切開したところ. 内容 は大網のみであった。

\section{結 語}

食道裂孔ヘルニアを合併し，大網のみを内容とした Morgagni 孔ヘルニアの1例を報告した. 診断には CT，MRIにて腹腔との連続性を見いだすことが重要 であると考えられた．手術経路としては胸骨䋖切開に よるアプローチで, 脆弱した横隔膜に対しメッシュ補 強は有用であった。

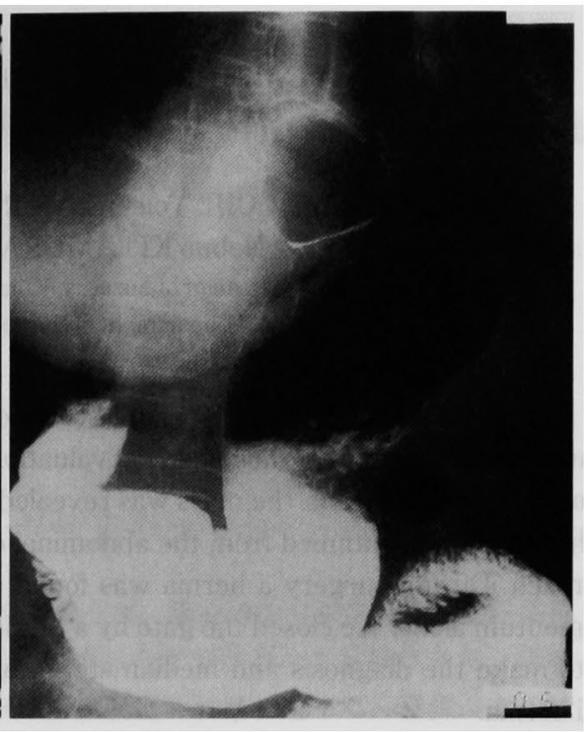

图 4 上部消化筐透視検亘：胃の立位充盈像にて滑脱 型食道裂孔へルニアが認められる。

\section{文臷}

1）豊田暢彦, 倉吉和夫，牧野正人他：胃および横行結 腸を内容とした Morgagni 孔へルニアの 1 例. 日 臨外医会誌 $52: 2083-2087,1991$

2）土肥英樹, 中川芳樹, 森田 実他 : Morgagni 孔へ ルニアの 3 治験例一主としてヘルニア内容と手術 程路に関する考察一. 日胸外会誌 $33: 2271 一$ 2275, 1985

3）富沢 傶, 牧野毁一, 橋都浩平他 : 乳児 Morgagni 孔ヘルニアの 2 症例一症例報告および本邦文献報 告例の検討一. 日小览外会誌 $16: 619-624,1980$

4）及川佑一郎, 村井英夫, 多田正人他：Morgagni 孔へルニアの3 症例. 日臨外医会誌 $50: 102-$ 106. 1989

5）入来敦久, 江川勝士, 山王邦博他 : Morgagni 孔へ ルニアの 3 症例. 日胸外会誌 $36: 141-146,1988$

6）橋本 哲, 伊藤重彦, 原 信介他：Morgagni ヘル ニアの自験例の検討. 日臨外医会誌 $47: 760$ 763,1986

7）藤原敏典, 河野和明, 森 文樹他 : 大網のみを内容 とした Morgagni 孔へルニアの1 例一胸部正中切 開経路の有用性一. 日臨外医会誌 $53: 1330$ 1333. 1992

8) Kamiya N, Yokoi K. Miyazawa N, et al : Morgagni hernia diagnosed by MRI. Surg today $26: 446-$ 448, 1996 


\title{
A CASE OF MORGAGNI HERNIA COMPLICATED WITH ESOPHAGEAL HIATAL HERNIA
}

\author{
Yuji YAMAGUCHI, Yoichi TABIRA, Takeshi MORI, Kanyu NAKANO, \\ Nobuo KITAMURA and Hiroaki HONGO* \\ First Department of Surgery. Kumamoto University School of Medicine \\ -Department of Surgery. Yamaga City Hospital
}

This paper presents a case of Morgagni hernia complicated with esophageal hiatal hernia. An 80-yearsold woman was admitted to the hospital for evaluation of an abnormal shadow on chest X-ray films. On computed tomographic (CT) scans, the mass was revealed to have fat density. Magnetic resonance imaging (MRI) showed that the mass continued from the abdominal cavity. A median sternotomy was employed for the surgical approach. During surgery a hernia was found at the foramen of Morgagni with a sac containing the greater omentum alone. We closed the gate by a Marlex mesh ${ }^{1 \mathrm{i}}$. From our experience, CT and MRI are useful in order to make the diagnosis and median sternotomy is considered one of useful surgical approaches for Morgagni hernia. 